\title{
Influence of environmental parameters on fish assemblage of a Neotropical river with a flood pulse regime, Central Brazil
}

\author{
Tatiana Lima de Meloํㅜ Francisco Leonardo Tejerina-Garro ${ }^{1}$ \\ and Cesar Enrique de Melo²
}

This study aims to determine which of twelve environmental parameters (five physicochemical and seven hydromorphological) influence on the fish assemblage structure of the lower Mortes River basin located in the Bananal floodplain of the Araguaia River basin, Central Brazil. Sampling was conducted in six stretches of $1000 \mathrm{~m}$ each during the high and low waters. Fish were captured using gill nets and environmental parameters were measured by portable equipment or determined visually. The coinertia analysis indicated that two physicochemical (dissolved oxygen and water transparency), and four hydromorphological (channel width and depth, riparian vegetation cover and type of the riverside substrate) parameters structure the fish assemblages, both driven by the regional hydrological patterns (flood pulse). These results are explained by fish-environmental parameters relationship characteristic of the aquatic Neotropical systems.

Este estudo determinou quais entre doze parâmetros ambientais (cinco físico-químicos e sete hidromorfológicos) influenciam na estrutura da assembleia de peixes do baixo rio das Mortes localizado na planície de inundação do Bananal, bacia do rio Araguaia, Brasil Central. As coletas foram realizadas em seis trechos de $1000 \mathrm{~m}$ cada durante os períodos de chuva e estiagem, nos quais 1036 peixes foram coletados utilizando-se redes de malhar e medidos os parâmetros ambientais utilizando equipamentos portáteis ou determinados visualmente. A análise de coinércia indicou que dois parâmetros físicos e químicos (oxigênio dissolvido e a transparência da água) e quatro hidromorfológicos (largura e profundidade da calha principal, cobertura da mata ripária e tipo de substrato da margem) estruturam a assembleia de peixes, ambos influenciados pelo regime hidrológico regional (pulso de inundação). Estes resultados são discutidos considerando a interação entre peixes e os parâmetros ambientais característicos dos sistemas aquáticos Neotropicais.

Key words: Ecological interactions, Physicochemical variables, Hydromorphology.

\section{Introduction}

One challenge in fish ecology is to obtain a functional knowledge of the response of populations and community to environmental variation and disturbances on a temporal and spatial scale (Winemiller et al., 2000). At a large-scale, studies emphasize abiotic factors structuring riverine fish assemblages in temperate and tropical regions (Tejerina-Garro et al., 2005). This situation is also observed in Neotropical rivers where the fish assemblage structure is reported to be influenced by geomorphological factors such as altitude (Suárez \& Petrere Júnior, 2007), physicochemical water characteristics such as dissolved oxygen, pH (Jackson et al., 2001; Silva et al., 2007), water temperature (Cetra \& Petrere, 2006), flow velocity (Willis et al., 2005) and discharge (Barretto \& Uieda, 1998), conductivity, dissolved oxygen and $\mathrm{pH}$ (Araújo et al., 2009), or habitat availability (Melo, 2000) and heterogeneity (Towsend, 1996; Willis et al., 2005). In addition, the fish assemblages are influenced by the riparian vegetation, which provides food and increases the availability of aquatic refuges for small fish species through the falling of tree trunks and branches into the water course (Casatti et al., 2003). In addition, leaves incorporated into the channel substrate favor the establishment of a diverse fauna that can be used as food by fish (Uieda \& Uieda, 2001).

Furthermore, the riparian vegetation hosts terrestrial

${ }^{1}$ Center of Aquatic Biology, Universidade Católica de Goiás - Campus II, Av. Engler s/n, Jardim Mariliza, 74605-010 Goiânia, GO, Brazil. tatimelo@yahoo.com, garro@ucg.br

${ }^{2}$ Ichthyology and Limnology Laboratory, Universidade Estadual do Mato Grosso, BR158 km148, 78690-000 Nova Xavantina, MT, Brazil. meloce@yahoo.com 
arthropods who are predated by fish that jump out of the water such as Osteoglossum bicirrhosum (Cuvier, 1829) (Santos et al., 2004) or when they fall in the water (Melo et al., 2004).

Otherwise, in a river-floodplain system, such as that of the Mortes River, the periodic inundation and drought (flood pulse) is the driving force (Junk \& Wantzen, 2003). It makes interactions between the aquatic and terrestrial environment possible (Junk et al., 1989), regulates the model of the aquatic communities (Quirós \& Baigún, 1985; Townsend, 1996; Rodrigues et al., 2002), propitiates the high diversity of the lotic environment associated to the floodplain because of the elevated heterogeneity of the habitat (Luiz et al., 2004; Thomaz et al., 2007), including in clear water rivers (sensu Sioli, 1984), such as the Mortes River, characterized by a low concentration of nutrients, but that support a rich aquatic flora and fauna (Goulding, 1993). It also modifies the limnological characteristics of rivers because of the quantities of organic matter received from the floodplain (Townsend, 1996), and influences the fish-environmental parameter relationship (Lin \& Caramaschi, 2005). However, Junk \& Wantzen (2003) state that systematized and detailed studies about the influence of the hydrology and hydrochemical parameters on flora and fauna of Neotropical rivers with a floodplain are scarce.

This study aims to responds to the following question: which of twelve environmental parameters (five physicochemical and seven hydromorphological) influence fish assemblages of a river-floodplain system?

\section{Material and Methods}

\section{Study area}

The Mortes River is the main affluent of the Araguaia River, Amazon basin, Central Brazil (Fig. 1). Its lower section is located within the Bananal floodplain, which covers around $70,000 \mathrm{~km}^{2}$ of the Mato Grosso State and extends along 600 $\mathrm{km}$ to the left of the Araguaia River (Brasil, 1982). The Mortes River basin is covered by Brazilian savanna (Cerrado), while some parts are used for agriculture and cattle raising. In its lower section the riparian vegetation may be continuous but interrupted occasionally by pasture. The right side of the river section sampled in this study borders the conservation unit of the Araguaia State Park. The regional climate is characterized by a rainy season (November to April) which causes annual flooding of the riparian vegetation and savanna (Lowe-McConnell, 1999) and allows the interconnection of the Bananal floodplain and the Araguaia and Mortes Rivers (Ribeiro et al., 1995). At low water levels, temporary sandy beaches are formed along the riverside and within the main channel.

\section{Sampling protocol}

Fish and environmental parameters were analyzed in six stretches located in the lower section of the Mortes River, Mato Grosso State (Fig. 1) during low (October 2004) and high (March 2005) water seasons. In each stretch (1000 m length), 11 transects were established every $100 \mathrm{~m}$. This length corresponds to the category "stretch" of the classification of
Imnhof et al. (1996). The geographic coordinates of the upstream and downstream bounds of each stretch and transect were taken using a GPS Garmin III.

Fish were captured using 20 gill nets (10 m length, $1.5 \mathrm{~m}$ width; mesh sizes of 30, 40, 60, 80 and $100 \mathrm{~mm}$ ) following the protocol suggested by Tejerina-Garro \& Mérona (2000) for tropical rivers. All gill nets were set from 17:30 to 7:30 with one inspection to reduce predation on captured fish. On site, collected fish were fixed in 10\% formaldehyde solution and in the laboratory they were measured (standard length), weighed and identified. Voucher specimens for all species were deposited in the Ichthyology and Limnology Laboratory at the Universidade Estadual do Mato Grosso, Campus Nova Xavantina.

Water samples were collected using a Van Dorn sampler at $0.50 \mathrm{~m}$ depth in the center of the river channel in the first, fifth and eleventh transect of each stretch. Then, the variables pH (QUIMIS model Q-400 BC), conductivity (QUIMIS model Q-405 B2), water temperature (mercury thermometer),

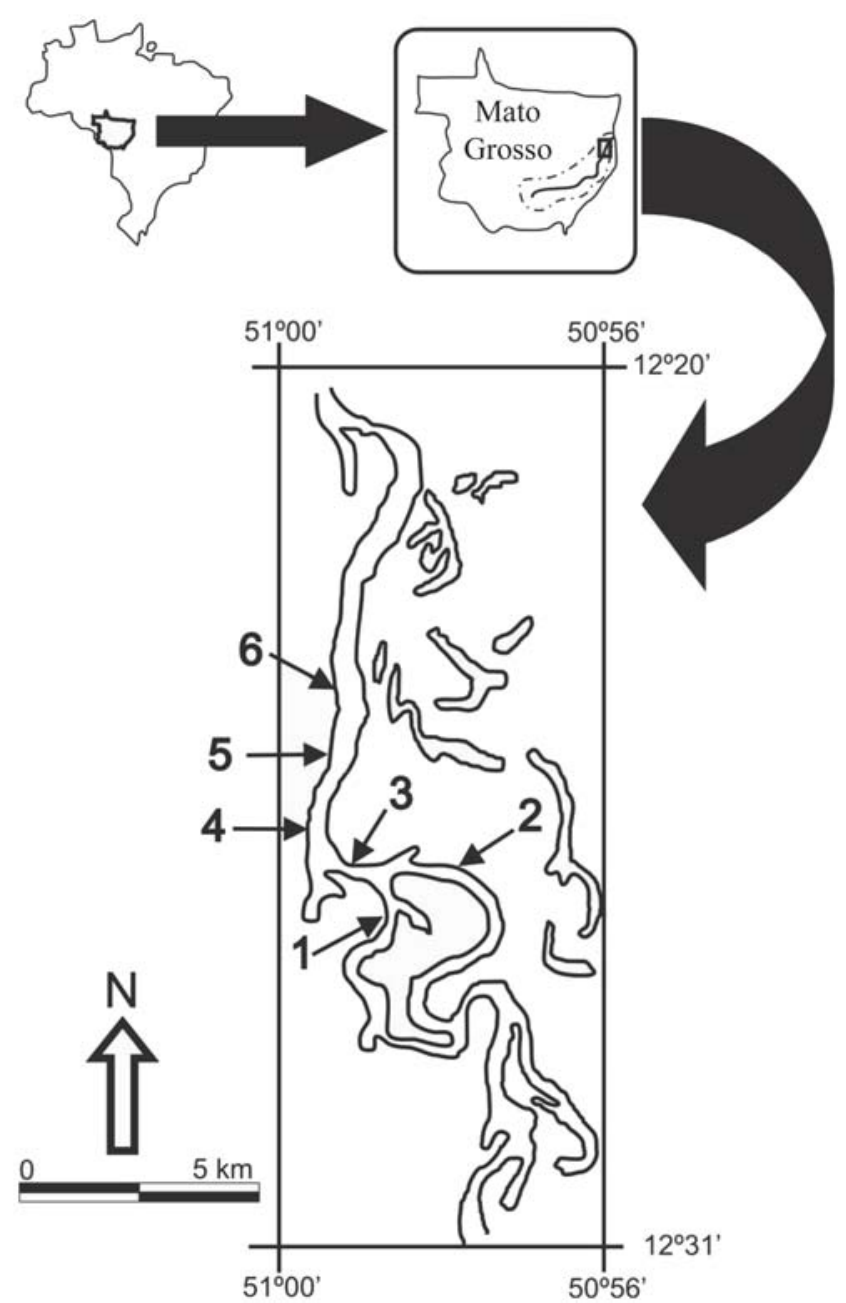

Fig. 1. Study area located in the lower section of the Mortes River, Bananal floodplain, Central Brazil. The boldface numbers correspond to the stretches sampled. 
dissolved oxygen (Winkler method; Pinto-Silva, 2002) and Secchi transparency (Esteves, 1988) were measured. The water depth (scaled rope), water velocity (General Electronics Model 2030) and channel length (GPS Garmin III) were measured at each transect.

The qualitative variables, that is, the type of riverside inclination (steep, little inclined, no incline), riverside substrate (sand, clay, leaves, roots, flooded), riparian vegetation (trees, shrubs, herbs, grass, flooded) and the riparian vegetation cover over the river channel (high, little, absent, flooded) were estimated at each transect and on both riversides of the stretch.

\section{Data analysis}

The fish data matrix was formed by the abundance per species, the qualitative variables was composed by the dominant or co-dominant categories of each variable, and the quantitative variables were the average. In all situation data was organized per stretch and water season. Afterwards, the matrices were submitted to a multivariate analysis of ordination in order to find patterns in the fish assemblage structure related to environmental parameters (McCune \& Grace, 2002). The following analyses were performed using the free ADE-4 software (Thioulouse et al., 1997):

Principal component analysis (PCAs) - separately provided the ordination of the fish species using the covariance method which is recommended when faunistic data are counted using the same type of measurement (abundance in this study), and quantitative variables by means of a correlation method that allows the comparison of data measured in different units (Dolédec \& Chessel, 1991).

Multiple component analysis (MCA) - used to ordinate multistate categorical variable arrays coded by qualitative criteria (Dolédec \& Chessel, 1991).

Co-inertia analysis (COIAs) - provided the ordination of the co-structure between the fish species and environmental parameters. This analysis is sensitive even when the number of samplings is reduced (Dolédec \& Chessel, 1994). Two COIAs were performed separately between the fish species ordination resulting from the PCA and the quantitative (PCA) and qualitative variables (MCA), both followed by a Monte Carlo test $(1000$ permutations; $p<0.05)$ in order to verify if the fishenvironmental parameter co-structures founds were random.

\section{Results}

There were collected 1036 specimens represented by 72 species, 18 families and five orders (Table 1 ). The abundance and richness were higher in the low water (659 specimens and 66 species, respectively) than in the high water season (377 specimens and 41 species; Table 1 ).

Two axes of each COIA were retained for interpretation of the co-structure between the fish species assemblages and the quantitative (95.8\% of total inertia explained) and qualitative (87.58\%) variables. The co-structures found in both analyses have high correlation in two axes $(r=0.79$ in axis $1, r=0.59$ in axis 2 for the quantitative variables; $r=0.93$ in axis 1 and $r=0.85$ in axis 2 for the qualitative variables) and are not random $(\mathrm{p}=0.001$ for the quantitative and $\mathrm{p}=0.021$ for the qualitative variables) (Table 2). In both ordinations, the co-structures found are influenced by seasonality (Figs. 2a-b).

In low waters, except stretches 2 and 4 , the fish assemblage represented by Serrasalmus gibbus, Serrasalmus eigenmanni, Triportheus auritus, Boulengerella cuvieri and Hydrolycus armatus was related to an environment characterized by a high value of dissolved oxygen (average $=6.70 \mathrm{mg} / \mathrm{l}$ ), high riparian vegetation cover, and a riverside substrate predominantly composed by sand, leaves and roots (Figs. 2a-b). In the same season and in stretch 2 the piranhas Serrasalmus rhombeus, Serrasalmus eigenmanni and Pygocentrus nattereri were related to low values of Secchi transparency (average $=78 \mathrm{~cm}$ ), whereas in stretch 4 P. nattereri, Hydrolycus tatauaia and Hemiodus unimaculatus were correlated to the absence/high riparian vegetation cover and a riverside substrate composed of sand and leaves (Fig. 2b, Table 3).

In high waters, except for stretch 5 , the fish assemblage represented by Auchenipterichthys coracoideus, Agoniates halecinus, Ageneiosus inermis and $R$. vulpinus was related to a deeper river channel (average $=397.85 \mathrm{~cm}$ ) with a flooded riverside resulting in a high area of the river channel covered by vegetation (Fig. 2; Table 3). In stretch 5 only A. halecinus was associated to a high water transparency $(101.67 \mathrm{~cm})$ and a channel width (355.45 m) (Fig. 2a, Table 3).

\section{Discussion}

Dissolved oxygen (DO) is the most important gas in the dynamic and characterization of the aquatic ecosystem (Welcomme, 1979; Esteves, 1988). It displays elevated concentration variability along a water course and is influenced by wind and water velocity, thermal effects and organic matter decomposition throughout the hydrological cycle (Bayley, 1995). In this study the average concentration of DO measured at low waters was higher than that during high waters. Bayley (1995) indicates that when the water level increases at high waters the decomposition of organic matter increases, resulting in the decrease of DO concentration values. This occurs mainly in the floodplain because of the lateral inundation. The water present in the floodplain has low DO concentrations probably resulting from the combination of elevated amounts of organic matter and the inhibiting effects of the vegetation cover over the aquatic photosynthesis process (Kramer et al., 1978). Like the DO concentration process, other modifications of the ecological conditions of rivers associated to floodplain occur resulting from periodic flooding and the intensity and duration of discharge, which creates transition zones between terrestrial and aquatic ecosystem (Junk \& Wantzen, 2003). This annual flooding influence fish species with different life strategies causing modifications in the composition and structure of fish assemblage (Agostinho et al., 2001) or single species (Castello, 2008), like in this study, where Boulengerella cuvieri, 
Table 1. Absolute abundance of the fish species sampled in the lower Mortes River during low (L) and high (H) waters.

\begin{tabular}{|c|c|c|c|c|c|c|c|}
\hline & Code & $\mathrm{H}$ & $\mathrm{L}$ & & Code & $\mathrm{H}$ & $\bar{L}$ \\
\hline CLUPEIFORMES & & & & Alestidae & & & \\
\hline Engraulidae & & & & Chalceus epakros Zanata \& Toledo-Piza, 2004 & Chaepa & 1 & 5 \\
\hline Lycengraulis batesii (Günther, 1868) & Lycbat & 1 & 4 & Cynodontidae & & & \\
\hline Pristigasteridae & & & & Cynodon gibbus (Agassiz, 1829) & Cyngib & 0 & 6 \\
\hline Pellona castelnaeana Valenciennes, 1847 & Pelcas & 10 & 1 & Hydrolycus armatus (Jardine \& Schomburgk, 1841) & Hydarm & 7 & 30 \\
\hline Pristigaster cayana Cuvier, 1829 & Pricay & 10 & 1 & Hydrolycus tatauaia Toledo-Piza, Menezes \& Santos, 1999 & Hydtat & 7 & 25 \\
\hline CHARACIFORMES & & & & Rhaphiodon vulpinus Spix \& Agassiz, 1829 & Rhavul & 48 & 18 \\
\hline Curimatidae & & & & Ctenoluciidae & & & \\
\hline Curimata cyprinoides (Linnaeus, 1766) & Curcyp & 0 & 9 & Boulengerella cuvieri (Agassiz, 1829) & Boucuv & 28 & 67 \\
\hline Cyphocharax spiluropsis (Eigenmann \& Eigenmann, 1889) & Cypspi & 2 & 0 & SILURIFORMES & & & \\
\hline Prochilodontidae & & & & Loricariidae & & & \\
\hline Prochilodus nigricans Spix \& Agassiz, 1829 & Pronig & 1 & 1 & Farlowella sp. & Farsp & 1 & 0 \\
\hline Semaprochilodus brama (Valenciennes, 1850) & Sembra & 3 & 1 & Hypoptopoma sp. & Hypsp & 3 & 1 \\
\hline Anostomidae & & & & Hypostomus sp. & Hypsp & 0 & 2 \\
\hline Laemolyta fernandezi Myers, 1950 & Laepet & 3 & 3 & Loricaria sp. & Lorsp & 0 & 3 \\
\hline Laemolyta taeniata (Kner, 1858) & Laetae & 2 & 0 & Pterygoplichthys sp. & Ptesp & 0 & 1 \\
\hline Leporinus affinis Günther, 1864 & Lepaff & 2 & 11 & Squaliforma emarginata (Valenciennes, 1840) & Squema & 2 & 14 \\
\hline Leporinus desmotes Fowler, 1914 & Lepdes & 0 & 1 & Sturisoma nigrirostrum Fowler, 1940 & Stunig & 1 & 1 \\
\hline Leporinus friderici (Bloch, 1794) & Lepfri & 0 & 4 & Pimelodidae & & & \\
\hline Schizodon vittatus (Valenciennes, 1850) & Schvit & 1 & 4 & Hemisorubim platyrhynchos (Valenciennes, 1840) & Hempla & 0 & 3 \\
\hline Chilodontidae & & & & Pimelodus blochii Valenciennes, 1840 & Pimblo & 0 & 9 \\
\hline Caenotropus labyrinthicus (Kner, 1858) & Caelab & 1 & 4 & Pinirampus pirinampu (Spix \& Agassiz, 1829) & Pinpir & 3 & 1 \\
\hline Hemiodontidae & & & & Pseudoplatystoma fasciatum (Linnaeus, 1766) & Psefas & 2 & 1 \\
\hline Anodus elongatus Agassiz, 1829 & Anoelo & 5 & 0 & Sorubim lima (Bloch \& Schneider, 1801) & Sorlim & 1 & 6 \\
\hline Hemiodus argenteus Pellegrin, 1908 & Hemarg & 0 & 8 & Zungaro zungaro (Humboldt, 1821) & Zunzun & 0 & 1 \\
\hline Hemiodus microlepis Kner, 1858 & Hemmic & 0 & 6 & Doradidae & & & \\
\hline Hemiodus unimaculatus (Bloch, 1794) & Hemuni & 4 & 20 & Hassar wilderi $\mathrm{Ki}$ & Haswil & 0 & 5 \\
\hline Characidae & & & & Auchenipteridae & & & \\
\hline Agoniates halecinus Müller \& Troschel, 1845 & Agohal & 23 & 1 & Ageneiosus inermis (Linnaeus, 1766) & Ageine & 49 & 16 \\
\hline Brycon falcatus Müller \& Troschel, 1844 & Bryfal & 0 & 1 & Ageneiosus sp. & Agesp & 16 & 8 \\
\hline Brycon pesu Müller \& Troschel, 1845 & Brypes & 0 & 8 & Auchenipterichthys coracoideus (Eigenmann \& Allen, 1942) & Auccor & 13 & 1 \\
\hline Brycon sp. & Brysp & 0 & 1 & Auchenipterus nuchalis (Spix \& Agassiz, 1829) & Aucnuc & 16 & 16 \\
\hline Bryconops alburnoides Kner, 1858 & Bryalb & 0 & 2 & BELONIFORMES & & & \\
\hline Moenkhausia sp. 2 & Moesp.2 & 0 & 1 & Belonidae & & & \\
\hline Myleus cf. раси (Jardine \& Schomburgk, 1841) & Mylpac & 2 & 0 & Pseudotylosurus sp. & Psesp & 2 & 0 \\
\hline Myleus schomburgkii (Jardine \& Schomburgk, 1841) & Mylsch & 0 & 2 & PERCIFORMES & & & \\
\hline Myleus torquatus (Kner, 1858) & Myltor & 1 & 7 & Sciaenidae & & & \\
\hline Pygocentrus nattereri Kner, 1858 & Pygnat & 40 & 101 & 1 Pachypops fourcroi (La Cepède, 1802) & Pacfou & 0 & 1 \\
\hline Serrasalmus eigenmanni Norman, 1929 & Sereig & 3 & 31 & Plagioscion squamosissimus (Heckel, 1840) & Plasqu & 1 & 3 \\
\hline Serrasalmus geryi Jégu \& Santos, 1988 & Serger & 2 & 11 & Cichlidae & & & \\
\hline Serrasalmus gibbus Castelnau, 1855 & Sergib & 19 & 53 & Cichla piquiti Kullander \& Ferreira, 2006 & Cicpiq & 0 & 1 \\
\hline Serrasalmus rhombeus (Linnaeus, 1766) & Serrho & 35 & 59 & Crenicichla lugubris Heckel, 1840 & Crelug & 0 & 1 \\
\hline Tetragonopterus argenteus Cuvier, 1816 & Tetarg & 0 & 4 & Crenicichla sp. & Cresp & 0 & 1 \\
\hline Tetragonopterus chalceus Spix \& Agassiz, 1829 & Tetcha & 0 & 6 & Geophagus sp. & Geosp & 0 & 2 \\
\hline Tetragonopterus sp. & Tetsp & 0 & 4 & Heros sp. & Hersp & 0 & 1 \\
\hline Triportheus albus Cope, 1872 & Trialb & 1 & 2 & Retroculus lapidifer (Castelnau, 1855) & Retlap & 0 & 1 \\
\hline Triportheus auritus (Valenciennes, 1850) & Triaur & 5 & 21 & Satanoperca sp. & Satsp & 0 & 2 \\
\hline Triportheus trifurcatus (Castelnau, 1855) & Tritri & 0 & 13 & & & & \\
\hline TOTAL & & 176 & 406 & & & 201 & 253 \\
\hline
\end{tabular}

Hydrolycus armatus, Triportheus auritus and Serrasalmus gibbus were related to oxygenated environments.

Changes in the river channel depth are related to oscillations of the hydrological cycle due to regional seasonality (Cellot et al., 1994; Thomaz et al., 2007). That was verified in this study, that is, the river channel was shallower during low waters than throughout high waters. This situation allied to the presence of the Bananal floodplain, promotes the migration of the littoral zones of the river (moving littoral sensu Junk et al., 1989). During high waters the increase of river water volume raises the river channel depth and causes lateral flooding, thereby displacing the riverside into the floodplain (Junk \& Wantzen, 2003). In this study Ageneiosus inermis, Agoniates halecinus and Rhaphiodon vulpinus were related to a deep channel. These are piscivorous species that inhabit the main river channel (Petry et al., 2003), where they could prey on fish that enter or leave on the flooded region.

The influence of Secchi transparency on fish assemblage structure in this study was mainly related to stretch 5 during high waters. However, no pronounced differences were observed in this parameter in stretch 5 between high and low waters (average $=91.67 \mathrm{~cm}$ ) as reported for the floodplain lakes of the Orinoco River (low waters $=5.00 \mathrm{~cm}$; high waters $=130.00$ cm; Rodriguez \& Lewis-Jr, 1997) or for the Araguaia River (low waters $=18.00 \mathrm{~cm}$; high waters $=132.00 \mathrm{~cm}$; Tejerina-Garro et al., 1998). This situation can be explained by the unidirectional 
Table 2. Summary of the co-inertia analysis between the fish assemblages and quantitative (A) and qualitative (B) environmental parameters. Boldface numbers point to the more important contributions to the co-structure.

\begin{tabular}{|c|c|c|c|}
\hline \multicolumn{2}{|l|}{ Environmental parameters } & \multicolumn{2}{|c|}{ Axis 1 Axis 2} \\
\hline \multicolumn{2}{|l|}{ (A) Quantitative } & & \\
\hline \multirow{2}{*}{\multicolumn{2}{|c|}{$\begin{array}{l}\text { Dissolved oxygen } \\
\text { pH }\end{array}$}} & 16.74 & 4.59 \\
\hline & & 10.19 & 1.78 \\
\hline \multicolumn{2}{|l|}{ Conductivity } & 8.78 & 14.29 \\
\hline \multicolumn{2}{|l|}{ Water temperature } & 12.72 & 6.01 \\
\hline \multicolumn{2}{|l|}{ Secchi transparency } & 1.24 & 50.87 \\
\hline \multicolumn{2}{|l|}{ Channel width } & 17.19 & 22.08 \\
\hline \multicolumn{2}{|l|}{ Water velocity } & 14.03 & 0.29 \\
\hline \multicolumn{2}{|c|}{ Statistics of the $\mathrm{Co}$-inertia analycic. } & 19.05 & 0.04 \\
\hline \multicolumn{4}{|c|}{ Statistics of the Co-inertia analysis: } \\
\hline Eigenvalue & & 576.02 & 27.86 \\
\hline \multicolumn{2}{|l|}{ Explained inertia (\%) } & 91.40 & 4.42 \\
\hline \multicolumn{2}{|l|}{$\begin{array}{l}\text { Total inertia explained (\%) } \\
\text { Correlation (r) fish species - environmental parameters }\end{array}$} & \multicolumn{2}{|c|}{95.82} \\
\hline \multirow{2}{*}{\multicolumn{2}{|c|}{$\begin{array}{l}\text { Correlation (r) fish species - environmental parameters } \\
\text { Monte Carlo test (1000 iterations) }\end{array}$}} & 0.79 & 0.59 \\
\hline & & \multicolumn{2}{|c|}{0.001} \\
\hline \multicolumn{2}{|l|}{ (B) Qualitative } & & \\
\hline \multirow{4}{*}{ Riverside inclination } & No incline/little inclined & 0.00 & 1.34 \\
\hline & Steep & 9.96 & 2.26 \\
\hline & No incline & 6.03 & 4.85 \\
\hline & Sand/clay/leaves & 0.21 & 1.61 \\
\hline \multirow{4}{*}{ Riverside substrate } & Sand/leaves & 33.65 & 6.88 \\
\hline & Sand/leaves/flooded & 1.56 & 6.45 \\
\hline & Flooded & 4.89 & 6.45 \\
\hline & Sand/leaves/roots & 0.18 & 25.91 \\
\hline \multirow{3}{*}{ Riparian vegetation } & Flooded & 3.26 & 0.21 \\
\hline & Trees/shrubs & 0.29 & 0.01 \\
\hline & Little & 1.14 & 0.02 \\
\hline \multirow{3}{*}{ Riparian vegetation cover } & High & 0.13 & 26.35 \\
\hline & Absent/high & 33.65 & 6.88 \\
\hline & Flooded & 4.98 & 10.13 \\
\hline \multicolumn{4}{|c|}{ Statistics of the Co-inertia analysis: } \\
\hline \multirow{2}{*}{\multicolumn{2}{|c|}{$\begin{array}{l}\text { Eigenvalue } \\
\text { Explained inertia (\%) }\end{array}$}} & 121.25 & 26.53 \\
\hline & & 71.83 & 15.75 \\
\hline \multirow{2}{*}{\multicolumn{2}{|c|}{$\begin{array}{l}\text { Total inertia explained (\%) } \\
\text { Correlation (r) fish species - environmental parameters }\end{array}$}} & \multicolumn{2}{|c|}{87.58} \\
\hline & & 0.93 & 0.85 \\
\hline \multicolumn{2}{|l|}{$\begin{array}{l}\text { Correlation (r) fish species - environmental parameters } \\
\text { Monte Carlo test (1000 iterations) }\end{array}$} & \multicolumn{2}{|c|}{0.021} \\
\hline
\end{tabular}

flow characteristics of lotic systems (Esteves, 1988), which impedes the temporal and spatial constancy of similar quantities of suspended material in the water column. This condition is necessary for the response of fish assemblages to water transparency modification according to the PTM model (Piscivory-Transparency-Morphometry) described by Rodriguez \& Lewis-Jr (1997). On the other hand, stretch 2 in both seasons showed low average values of Secchi transparency, channel width and channel depth in relation to the other stretches. This seems to be related to its similarity with a lentic environment, or a branch of a river with a lower water flow during both seasons. These conditions could favor the presence of prey species and could explain the presence of fish predators such as Auchenipterichthys coracoideus, Rhaphiodon vulpinus, Ageneiosus inermis and the piranhas Serrasalmus rhombeus, Serrasalmus eigenmanni and Pygocentrus nattereri, the latter associated with lentic waters (Goulding, 1980).

Aquatic environments are influenced by geology and vegetation (Allan \& Johnson, 1997), the latter influencing the formation of the riparian vegetation (Bunn et al., 1999; Growns et al., 2003) that can totally or partially cover the river channel.
In this study, the parameter riparian vegetation cover influences the fish assemblage structure. This influence seems to be related to the availability of refuges into the flooded vegetation (tree branch and trunk, and roots; Welcomme, 1979) and food represented by aquatic invertebrates and algae fixed to the substrate (Horeau et al., 1998; Naiman \& Décamps, 1997; Barrella et al., 2001), arthropods (Goulding, 1993; Horeau et al., 1996) and fruits and seeds (Goulding et al., 1988; Goulding, 1993) falling from the flooded vegetation. This situation seems to explain the association of the insectivore Triportheus auritus, detritivore Curimata cyprinoides and omnivore Brycon pesu (Santos et al., 2004; Melo et al., 2005) with the riparian vegetation cover parameter in this study. Incidentally, other predator fish such as Pygocentrus nattereri, Serrasalmus rhombeus and Hydrolycus tatauaia were also related to this parameter. Serrasalmus rhombeus is reported to inhabit areas near the riverside in both seasons (low and high waters) displaying an ambush hunting strategy in both the main river channel and flooded areas (Goulding, 1980). The preference of Boulengerella cuvieri for sandy beaches where it hunts its prey (Arrington \& Winemiller, 2003) could explain its association with stretches without riparian 
Table 3. Average values and standard deviation (in parentheses) of the quantitative environmental parameters measured in the six stretches during low (L) and high (H) waters.

\begin{tabular}{lcccccccc}
\hline Stretch & $\begin{array}{c}\text { Dissolved } \\
\text { oxygen }(\mathrm{mg} / \mathrm{l})\end{array}$ & $\mathrm{pH}$ & $\begin{array}{c}\text { Conductivity } \\
\left(\mu \mathrm{S} . \mathrm{cm}^{-1}\right)\end{array}$ & $\begin{array}{c}\text { Water } \\
\text { temperature } \\
\left({ }^{\circ} \mathrm{C}\right)\end{array}$ & $\begin{array}{c}\text { Secchi } \\
\text { transparency } \\
(\mathrm{cm})\end{array}$ & $\begin{array}{c}\text { Channel } \\
\text { width }(\mathrm{m})\end{array}$ & $\begin{array}{c}\text { Water velocity } \\
(\mathrm{cm} / \mathrm{s})\end{array}$ & $\begin{array}{c}\text { Channel } \\
\text { depth }(\mathrm{cm})\end{array}$ \\
\hline 1L & $6.60(0.10)$ & $6.87(0.06)$ & $8.20(0.17)$ & $30.00(0.00)$ & $84.67(2.08)$ & $222.73(16.79)$ & $28.82(10.33)$ & $145.86(120.19)$ \\
2L & $6.86(0.01)$ & $6.90(0.10)$ & $8.33(0.23)$ & $32.00(2.89)$ & $78.00(12.12)$ & $154.55(17.53)$ & $22.77(4.70)$ & $78.86(40.19)$ \\
3L & $6.93(0.07)$ & $6.40(0.44)$ & $8.90(0.52)$ & $32.50(0.76)$ & $87.33(10.97)$ & $212.73(18.49)$ & $22.00(7.96)$ & $110.73(60.80)$ \\
4L & $6.71(0.00)$ & $6.83(0.06)$ & $9.77(1.59)$ & $32.50(0.50)$ & $90.00(1.73)$ & $207.27(11.91)$ & $18.18(3.42)$ & $85.23(27.17)$ \\
5L & $6.41(0.07)$ & $7.00(0.00)$ & $9.30(0.87)$ & $33.00(0.00)$ & $91.67(2.89)$ & $285.00(19.87)$ & $28.00(13.80)$ & $136.64(92.59)$ \\
6L & $6.71(0.22)$ & $6.83(0.06)$ & $8.00(0.10)$ & $31.00(0.29)$ & $84.67(5.13)$ & $312.73(10.09)$ & $25.00(7.02)$ & $164.36(81.25)$ \\
1H & $4.96(0.27)$ & $6.17(0.01)$ & $13.00(0.70)$ & $22.00(0.00)$ & $86.00(3.00)$ & $378.18(22.28)$ & $29.86(13.61)$ & $339.27(167.59)$ \\
2H & $5.12(0.01)$ & $6.66(0.03)$ & $12.83(0.21)$ & $28.00(0.00)$ & $73.00(0.58)$ & $221.82(22.28)$ & $53.36(16.10)$ & $333.64(53.30)$ \\
3H & $5.11(0.22)$ & $6.07(0.12)$ & $12.50(0.17)$ & $29.00(0.00)$ & $80.00(0.00)$ & $325.45(25.05)$ & $54.14(15.91)$ & $413.86(101.06)$ \\
4H & $4.64(0.17)$ & $6.39(0.05)$ & $11.90(0.36)$ & $29.00(0.00)$ & $88.33(2.89)$ & $263.64(15.02)$ & $54.59(18.09)$ & $416.64(109.62)$ \\
5H & $5.17(0.06)$ & $6.56(0.10)$ & $10.63(0.38)$ & $28.00(0.00)$ & $101.67(2.89)$ & $355.45(9.34)$ & $49.41(20.80)$ & $381.23(123.36)$ \\
6H & $5.40(0.06)$ & $6.26(0.04)$ & $11.33(0.67)$ & $27.00(0.29)$ & $90.00(0.00)$ & $370.00(11.83)$ & $58.68(18.80)$ & $395.86(105.54)$ \\
\hline
\end{tabular}
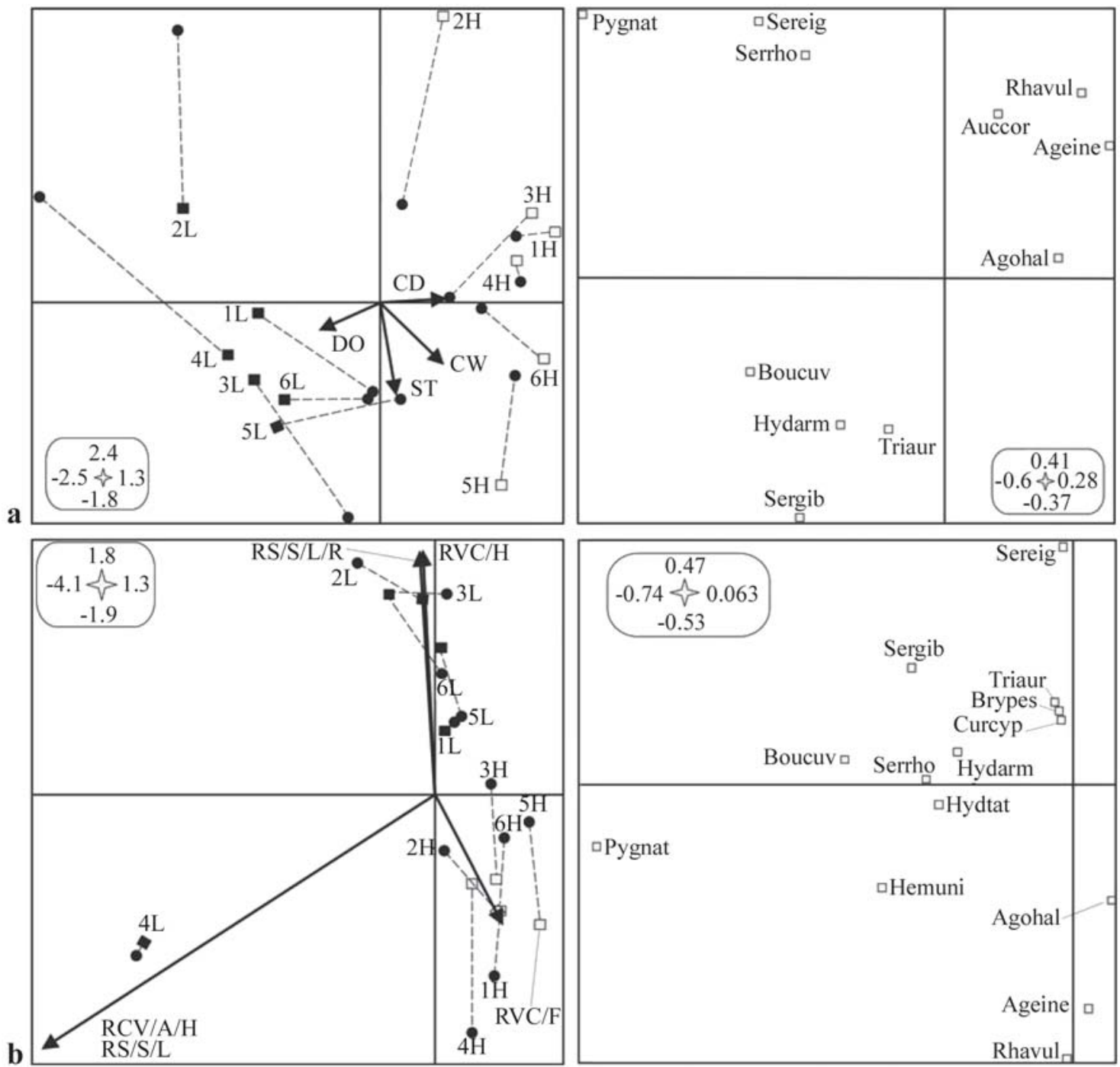

Fig. 2. Ordination of the co-structure resulting from the co-inertia analysis between the fish assemblages and quantitative (a) and qualitative (b) environmental parameters (square arrow edge $=$ stretch; circle $=$ fish assemblage). Numbers represent the stretch sampled at low $(\mathrm{L})$ or high $(\mathrm{H})$ waters. Letter codes correspond to the main fish species that contributed to the costructure and are listed in Table 1. CD = channel depth; CW = channel width; DO = dissolved oxygen; ST = Secchi transparency; $\mathrm{RS} / \mathrm{S} / \mathrm{L} / \mathrm{R}$ = river substrate/sand/leaves/roots; $\mathrm{RVC} / \mathrm{H}$ = river vegetation cover/high; $\mathrm{RVC} / \mathrm{A} / \mathrm{H}$ = river vegetation cover absent/ high; RS/S/L = river substrate/sand/leaves; RVC/F = river vegetation cover/flooded. Boxes indicate scales. 
vegetation covers. However, the association of fish species to the riparian vegetation cover parameter can be related to shaded areas, where the decrease in water temperature caused by vegetation cover allows micro-habitats to be explored (Naiman \& Décamps, 1997; Barrella et al., 2001; Growns et al., 2003).

In this study, of the twelve environmental parameters measured two physicochemical (dissolved oxygen and Secchi transparency) and four geomorphological (channel depth and width, riverside substrate and riparian vegetation cover) structure the fish assemblages, both driven by the flood pulse. These results are explained by fish-environmental parameter relationship characteristic of the aquatic Neotropical systems. However, the Secchi transparency does not show any pronounced contrast values between low and high waters, which is necessary for the response of fish assemblages according to the PTM model.

Studies like this may contribute to guide environmental management and efforts on conservation of the Mortes River basin, whose east side area until the Araguaia River constitutes one of the few regions of the Mato Grosso State, Central Brazil, not entirely transformed by anthropogenic activities (Anacleto et al., 2005).

\section{Acknowledgements}

The authors thank the Ichthyology and Limnology Laboratory team at the Universidade Estadual do Mato Grosso, campus Nova Xavantina, for laboratory and field support, two anonymous reviewers for their useful commentaries, and Patrick John O'Sullivan for checking the English. This study was conducted with funds from the Fundação Estadual do Meio Ambiente, Mato Grosso.

\section{Literature Cited}

Agostinho, A. A., L. C. Gomes \& M. Zalewski. 2001. The importance of floodplain for the dynamics of fish communities of the upper river Parana. Ecohydrology \& Hydrobiology, 1(1-2): 209-217.

Allan, D. J. \& L. B. Johnson. 1997. Catchment - scale analysis of aquatic ecosystems. Freshwater Biology, 37: 107-111.

Anacleto, T. C. da S., A. A. Ferreira, J. A. F. Diniz-Filho \& L. G. Ferreira. 2005. Seleção de áreas de interesse ecológico através de sensoriamento remoto e de otimização matemática: um estudo de caso no município de Cocalinho, MT. Acta Amazonica, 35(4): 437-444.

Araújo, F. G., B. C. T. Pinto \& T. P. Teixeira. 2009. Longitudinal patterns of fish assemblages in a large tropical river in southeastern Brazil: evaluating environmental influences and some concepts in river ecology. Hydrobiologia, 618(1): 89-107.

Arrington, D. A. \& K. O. Winemiller. 2003. Organization and maintenance of fish diversity in shallow waters of tropical floodplain rivers. Pp. 25-36. In: Welcomme, R. L. \& T. Petr (Eds.). Proceedings of the Second International Symposium on the Management of Large Rivers for Fisheries Volume 2. Food and Agriculture Organization of the United Nations \& Mekong River Commission. FAO Regional Office for Asia and the Pacific. Bangkok, RAP Publication, 285p.

Barrella, W., M. Petrere-Jr, W. S. Smith \& L. F. A. Montag. 2001.
As relações entre as matas ciliares, os rios e os peixes. Pp. 187207. In: Rodrigues, R. R. \& H. F. Leitão-Filho (Eds.). Matas ciliares. Conservação e recuperação. $2^{\mathrm{a}}$ ed. São Paulo, Editora Universidade de São Paulo, FAPESP, 320p.

Barretto, M. G. \& V. S. Uieda. 1998. Influence of the abiotic factors on the ichthyofauna composition in different orders stretches of Capivara River, São Paulo State, Brazil. Verhandlungen des Internationalen Verein Limnologie, 26: 2180-2183.

Bayley, P. B. 1995. Understanding large river-floodplain ecosystems: significant economic advantages and increased biodiversity and stability would result from restoration of impaired systems. Bioscience, 45(3): 153-158.

Brasil. 1982. Ministério do Interior. PRODIAT. Diagnóstico da bacia Araguaia-Tocantins. Brasília. 2V. (Recursos Naturais).

Bunn, S. E., P. M. Davies \& T. D. Mosisch. 1999. Ecosystem measures of river health and their response to riparian and catchment degradation. Freshwater Biology, 41: 333-345.

Casatti, L., M. F. Mendes \& K. M. Ferreira. 2003. Aquatic macrophytes as feeding site for small fishes in the Rosana reservoir, Paranapanema River, Southeastern Brazil. Brazilian Journal of Biology, 63(2): 213-222.

Castello, L. 2008. Lateral migration of Arapaima gigas in floodplains of the Amazon. Ecology of Freshwater Fish, 17: 38-46.

Cellot, B., M. J. Dole-Olivier, G. Bornette \& G. Pautou. 1994. Temporal and spatial environmental variability in the upper Rhône River and its floodplain. Freshwater Biology, 31: 311-325.

Cetra, M. \& M. Petrere Jr. 2006. Fish-assemblage structure of the Corumbataí River basin, São Paulo State, Brazil: characterization and anthropogenic disturbances. Brazilian Journal of Biology, 66: 431-439.

Dolédec, S. \& D. Chessel. 1991. Recent developments in linear ordination methods for environmental sciences. Advances in Ecology, 1: 133-155.

Dolédec, S. \& D. Chessel. 1994. Co-Inertia analysis: an alternative method for studying species-environment relationships. Freshwater Biology, 31: 277-294.

Esteves, F. A. 1988. Fundamentos de Limnologia. Rio de Janeiro, Interciência, 575p.

Goulding, M. 1980. The fishes and the forest. Explorations in Amazonian natural history. California, University of California Press, 280p.

Goulding, M. 1993. Flooded forests of the Amazon. Scientific American March, 114-120.

Goulding, M., M. L. Carvalho \& E. G. Ferreira. 1988. Rio Negro, rich life in poor water. Netherlands, SPB Academic Publishing, 200p.

Growns, I., P. C. Gehrke, K. L. Astles \& D. A. Pollard. 2003. A comparison of fish assemblages associated with different riparian vegetation types in the Hawkesbury-Nepean River system. Fisheries Management and Ecology, 10: 209-220.

Horeau, V., P. Cerdan, A. Champeau \& S. Richard. 1996. Importance des apports exogènes dans le régime alimentary de quelques poisons de "criques” Du bassin versant Du fleuve Sinnamary (Guyane Française). Revue d’Ecologie (La Terre et la Vie), 51: 29-41.

Horeau, V., P. Cerdan, A. Champeau \& S. Richard. 1998. Importance of aquatic invertebrates in the diet of rapids-dwelling fish in the Sinnamary River, French Guiana. Journal of Tropical Ecology, 14: 851-864.

Imnhof, J. G., J. Fitzgibbon \& W. K. Annable. 1996. A hierarchical evaluation system for characterizing watershed ecosystems for fish habitat. Canadian Journal of Fisheries and Aquatic Sciences, 53(1): 312-326.

Jackson, D. A., P. R. Peres-Neto \& J. D. Olden. 2001. What controls 
who is where in freshwater fish communities - the roles of biotic, abiotic, and spatial factors. Canadian Journal of Fisheries and Aquatic Sciences, 58: 157-170.

Junk, W. J., P. B. Bayley \& R. E. Sparks. 1989. The flood pulse concept in river-floodplain ecosystems. Pp. 110-117. In: Dodge, D. P. (Ed.). Proceedings of the international large river symposium. Canadian Special Publication of Fisheries and Aquatic Sciences, 106.

Junk, W. J. \& K. M. Wantzen. 2003. The flood pulse concept: new aspects, approaches and applications - an update. Pp. 117-140. In: Welcomme, R. L. \& T. Petr (Eds.). Proceedings of the Second International Symposium on the Management of Large Rivers for Fisheries. Volume 2. Food and Agriculture Organization of the United Nations \& Mekong River Commission. FAO Regional Office for Asia and the Pacific. Bangkok, RAP Publication, 285p.

Kramer, D. L., C. C. Lindsey, G. E. E. Moodie \& E. D. Stevens. 1978. The fishes and aquatic environment of the central Amazon basin, with particular reference to respiratory patterns. Canadian Journal of Zoology, 56: 717-729.

Lin, D. S. C. \& E. P. Caramaschi. 2005. Responses of the fish community to the flood pulse and siltation in a floodplain lake of the Trombetas River, Brazil. Hydrobiologia, 545: 75-91.

Luiz, E. A., K. D. G. Luz, R. S. Costa, J. D. Latini, H. F. JúlioJúnior \& L. C. Gomes. 2004. Structure of the fish assemblage in biotopes and subsystems of the upper Paraná River floodplain. Pp. 117-123. In: Agostinho, A. A., L. Rodrigues, L. C. Gomes, S. M. Thomaz \& L. E. Miranda (Eds.). Structure and functioning of the Paraná River and its floodplain. Maringá, Editora da Universidade Estadual de Maringá, 275p.

Lowe-McConnell, R. H. 1999. Estudos ecológicos de comunidades de peixes tropicais. São Paulo, Editora da Universidade de São Paulo, 584p.

McCune, B. \& J. B. Grace. 2002. Analysis of ecological communities. Oregon, mjm, 300p.

Melo, C. E. 2000. Ecologia comparada da ictiofauna em córregos de cerrado do Brasil Central: bases para a conservação das espécies. Unpublished Ph. D. Dissertation, Universidade Federal de São Carlos, São Paulo, 84p.

Melo, C. E., J. D. Lima, T. L. Melo \& V. Pinto-Silva. 2005. Peixes do Rio das Mortes. Identificação e ecologia das espécies mais comuns. Mato Grosso, Cáceres, Editora da Universidade do Estado de Mato Grosso, 145p.

Melo, C. E., F. A. Machado \& V. Pinto-Silva. 2004. Feeding habitats of fish from a stream in the savanna of Central Brazil, Araguaia Basin. Neotropical Ichthyology, 2(1): 37-44.

Naiman, R. J. \& H. Décamps. 1997. The ecology of interfaces: riparian zones. Annual Review of Ecology Systematics, 28: 621-658.

Petry, P., P. B. Bayley \& D. F. Markle. 2003. Relationships between fish assemblages, macrophytes and environmental gradients in the Amazon River floodplain. Journal of Fish Biology, 63: 547-579.

Pinto-Silva, V. 2002. Manual de análise limnológica: métodos e técnicas. Cuiabá, Editora da Universidade Federal de Mato Grosso, Mato Grosso, 95p.

Quirós, R. \& C. Baigún. 1985. Fish abundance related to organic matter in the Plata river basin, South America. Transactions of the American Fisheries Society, 114: 377-387.

Ribeiro, M. C. L. B., M. Petrere-Jr \& A. A. Juras. 1995. Ecological integrity and fisheries ecology of the Araguaia-Tocantins River basin, Brazil. Regulated Rivers: Research \& Management, 11: 325-350.

Rodriguez, M. A. \& W. M. Lewis-Jr. 1997. Structure of fish assemblages along environmental gradients in floodplains lakes of the Orinoco River. Ecological Monographs, 67: 109-128.
Rodrigues, L. C., S. Train, M. C. Roberto \& T. A. Pagioro. 2002. Seasonal fluctuation of some limnological variables on a floodplain lake (Patos lagoon) of the Upper Parana River, Mato Grosso do Sul State, Brazil. Brazilian Archives of Biology and Technology, 45(4): 499-513.

Santos, G. M., B. Mérona, A. A. Juras \& M. Jégu. 2004. Peixes do baixo Rio Tocantins: 20 anos depois da Usina Hidrelétrica Tucuruí. Brasília, Eletronorte, 216p.

Sioli, H. 1984. The Amazon and its main affluent: hydrology, morphology of the river courses and river types. Pp. 127-165. In: Sioli, H. (Ed.). Amazon: limnology and landscape ecology of a mighty tropical river and its basin. Boston, Dr. W. Junk Publishers, 747p.

Silva, E. F., C. E. Melo \& P. C. Venere. 2007. Fatores que influenciam a comunidade de peixes em dois ambientes no baixo Rio das Mortes, Planície do Bananal, Mato Grosso, Brasil. Revista Brasileira de Zoologia, 24(2): 482-492.

Súarez, Y. R. \& M. Petrere Júnior. 2007. Environmental factors predicting fish community structure in two neotropical rivers in Brazil. Neotropical Ichthyology, 5: 61-68.

Tejerina-Garro, F. L., R. Fortin \& M. A. Rodriguez. 1998. Fish community structure in relation to environmental variation in floodplain lakes of the Araguaia River, Amazon basin. Environmental Biology of Fishes, 51: 399-410.

Tejerina-Garro, F. L., M. Maldonado, C. Ibáñez, D. Pont, N. Roset. \& T. Oberdorff. 2005. Effects of natural and anthropogenic environmental changes on riverine fish assemblages: a framework for ecological assessment of rivers. Brazilian Archives of Biology and Technology, 48(1): 91-108.

Tejerina-Garro, F. L. \& B. Mérona. 2000. Gill net sampling standardization in large rivers of French Guiana (South America). Bulletin Français de la Pêche et de la Pisciculture, 357-358: 227-240.

Thioulouse, J., D. Chessel, S. Doldec \& J-M. Olivier. 1997. ADE4: a multivariate analysis and graphical display software. Statistics and Computing, 7: 75-83.

Thomaz, S. M., L. M. Bini \& R. L. Bozelli. 2007. Floods increase similarity among aquatic habitats in river-floodplain systems. Hydrobiologia, 579: 1-13.

Townsend, C. R. 1996. Concepts in river ecology: pattern and process in the catchment hierarchy. Archiv für Hydrobiologie, 113(10): 1-21.

Uieda, V. S. \& W. Uieda. 2001. Species composition and spatial distribution of a stream fish assemblage in the east coast of Brazil: comparison of two field study methodologies. Brazilian Journal of Biology, 61(3): 377-388.

Welcomme, R. L. 1979. Fisheries ecology of floodplain rivers. London, Longmans, 317p.

Willis, S. C., K. O. Winemiller \& H. Lopez-Fernandez. 2005. Habitat structural complexity and morphological diversity of fish assemblages in a Neotropical floodplain river. Oecologia, 142: 284-295.

Winemiller, K. O., S. Tarim, D. Shormann \& J. B. Cotner. 2000. Fish assemblage structure in relation to environmental variation among Brazos River oxbow lakes. Transactions of the American Fisheries Society, 129: 451-468.

Accepted June 26, 2009 Published September 30, 2009 